\title{
Pengaruh Politik Domestik terhadap Dinamika Bantuan Luar Negeri Chile
}

\author{
Muhaimin Zulhair Achsin ${ }^{1}$, Eveline Sisilia ${ }^{2}$ \\ ${ }^{1}$ Program Studi Hubungan Internasional, Universitas Brawijaya, Malang - Indonesia \\ ${ }^{2}$ Program Studi Hubungan Internasional, Universitas Brawijaya, Malang - Indonesia \\ Email:muhaimin.zul@ub.ac.id \\ Submitted: 15 Juni 2020 | Accepted: 30 Juni 2020
}

\begin{abstract}
One of the most significant changes in foreign aid issues has been the emerging of several nontradional donors as providers of foreign aid. One of these new emerging donor countries is Chile, the top five economies (GDP) in Latin America, one of the two of OECD Latin America members, and one of upper-middle income countries. Chile government started designing the foreign aid agency in 1990 through AGCI (The Chilean International Co-operation Agency), in a democracy transition era from Pinochet to Aylwin. This research attempts to analyze how Chile domestic political factors influence changes in the dynamics of Chile's ODA (Official Development Assistance), from aid-recipient to aid-provider. By using a theory from Lancester, the results are the domestic political factors namely ideas, institutions, interests (interest groups), and organizations influence the dynamic of Chile's foreign aid. However, the major obstacle in early phase of developing the agendas was coming from the military.
\end{abstract}

Keywords: Chile, Domestic, Politics, Foreign, Aid.

\begin{abstract}
Abstrak
Salah satu perubahan besar dalam isu bantuan luar negeri adalah munculnya beberapa negara donor non-tradisional sebagai penyedia bantuan. Salah satu dari negara donor baru ini adalah Chile, negara dalam peringkat lima teratas berdasarkan ekonomi (GDP) di Amerika latin, satu dari dua negara anggota OECD di kawasan Amerika Latin, dan salah satu negara berpendapatan menengah atas di dunia. Pemerintah Chile memulai mendesain agensi bantuan luar negri pada tahun 1990 melalui AGCI (The Chilean International Co-operation Agency), dalam suatu era transisi demokrasi dari Pinochet ke Aylwin. Penelitian ini berusaha menganalisa bagaimana faktor politik domestic di Chile memengaruhi dinamika bantuan luar negeri Chile, dari penerima bantuan ke pemberi bantuan. Dengan menggunakan teori dari Lancester, hasilnya faktor politik domestik ide, institusi, kepentingan (kelompok kepentingan), dan organisasi memengaruhi dinamika bantuan luar negeri Chile. Meskipun begitu, terdapat hambatan besar pada awal agenda bantuan luar negeri ini dibangun yaitu hambatan yang datang dari militer.
\end{abstract}

Kata Kunci: Bantuan, Luar Negeri, Chile, Politik, Domestik.

\section{PENDAHULUAN}

Dinamika geo-ekonomi dalam era globalisasi pasca-Perang Dingin menunjukkan persebaran kekayaan dan kekuatan ekonomi negara-negara di berbagai kawasan lebih bervariasi dibandingkan era sebelumnya.
Beberapa negara lower-middle income bergerak perlahan tapi pasti menuju middle \& upper- middle income. Kemampuan menyediakan bantuan luar negeri tidak terlepas dari perekonomian yang membaik. 
Emma Mawdsley (2012, pp. 1719) mencatat setidaknya ada tiga gelombang munculnya negara dengan kekuatan ekonomi baru di awal abad 21 yaitu: pertama, BRIC (Brazil, Rusia, India, China) berdasarkan prediksi dari Goldman Sachs pada tahun 2003. Kedua, CIVETS (Colombia, Indonesia, Vietnam, Egypt, Turkey, South Africa) berdasarkan analisa Robert Ward dari Economist Intelligence Unit. Ketiga, Argentina, Chile, Hungary, Malaysia dan Poland. Gelombang ini tidak mirip dengan fenomena ekonomi di tahun 1980an - 1990an misalnya East Asian Miracle.

Latvia dan Estonia di Eropa bagian utara; Afrika Selatan di Afrika; Uni Emirat Arab, Qatar, Israel, Arab Saudi, dan Turki di Timur Tengah; India, China, Indonesia dan Thailand di Asia Selatan, Timur dan Tenggara, merupakan negara-negara emerging donors di abad 21. Di kawasan Amerika Latin sendiri terdapat Chile dan Mexico (anggota OECD), Brazil dan Colombia yang turut berkiprah sebagai emerging donors. Data Bank Dunia (2020) menunjukkan GNI (Gross National Income) per kapita Chile pada tahun 1990 sejumlah USD 4.270 naik menjadi USD 23.750 pada tahun 2018 .

Namun tidak semua negara penyedia bantuan luar negeri menjadi topik pembicaraan arus utama, misalnya Kuba dan Venezuela di Amerika Latin. Kuba sejak tahun 1960an menyediakan bantuan luar negeri berupa tenaga kesehatan dan obat-obatan dalam misi kemanusiaan internasional yang telah hadir di banyak negara yang mengalami kesulitan karena wabah, bencana alam dan sebagainya (Kirk, 2015).

Ini bisa terjadi karena negaranegara tersebut tidak masuk ke dalam "game" rezim arus utama DAC (Development Assistance Committee) dengan seperangkat definisi, standar, hal teknis lainnya, serta tentu saja pelaporan kegiatan dan nilai bantuan. Tidak ada keharusan juga bagi Kuba untuk masuk ke arus utama semenjak Kuba mempunyai karakteristik dan modelnya tersendiri.

Karakteristik kemunculan negara donor baru ini pun berbeda dengan model donor tradisional, bermodel southern turn. Pada awalnya bantuan vertikal dari negara kaya ke miskin (negara Utara ke Selatan), berubah menjadi bantuan horizontal antara sesama negara Selatan-Selatan. Pada beberapa sudut praktik menantang kemapanan aturan main arus utama.

Identitas bagi negara middle-income sebagai pendonor memberi angin segar untuk mencapai kepentingan politik luar negeri suatu negara. Nilma Guljarani \& Liam Swiss (2017) memberi istilah fenomena ini sebagai era pencerahan negara-negara donor baru. Ada pertumbuhan kesadaran negaranegara non-DAC tentang peran dan identitas mereka sebagai negara pemberi bantuan. Negara-tersebut 
mencoba masuk ke dalam "game" DAC yaitu dengan melaporkan aktivitas dan nilai ODA (Official Development Assistance) ke pihak DAC sebagai regulator.

Chile sebagai emerging donor menjadi menarik untuk diteliti karena masyarkat di negara Chile pernah sangat kesulitan di era pemerintahan otoriter Pinochet selama kurang dari 17 tahun. Naomi Klein (2007, p. 76) menyatakan bahwa Chile sama sekali tidak mempunyai pengalaman kekerasan. Chile menikmati 160 tahun demokrasi damai sampai ketika Pinochet datang menggulingkan Allende pada tahun 1973 dan menjalankan pemerintahan dengan teror.

Setelah pemerintahan junta militer Pinochet mengalami transisi demokrasi ke pemerintahan Presiden Aylwin, terbentuk pula badan pengelola bantuan luar negeri di Chile melalui AGCI (Agencia de Cooperación Internacional de Chile/ The Chilean International Cooperation Agency). AGCI kemudian didirikan pada bulan Juli tahun 1990 untuk membantu pemerintah waktu itu dalam menyalurkan bantuan luar negeri ke berbagai saluran domestik.

Pembentukan AGCI tidak bisa dilepaskan dari iklim dan struktur politik domestik yang membaik (transisi demokrasi) selepas masa pemerintahan junta rezim Pinochet. Hal ini dimulai dari plebisit tahun 1988 yang berisi penolakan perpanjangan masa kekuasaan Pinochet sampai tahun 1997, serta naiknya Aylwin dari koalisi kiri tengah menjadi presiden pada bulan Maret 1990 setelah memenangkan pemilihan pada Desember 1989.

Oleh karenanya, menarik untuk melihat dinamika bantuan luar negeri Chile dari sudut pandang politik domestik. Penelitian ini mengajukan pertanyaan bagaimana politik domestik memengaruhi dinamika bantuan luar negeri Chile? Tekanan penjelasan faktor domestik pada tulisan ini adalah di era awal transisi-konsolidasi demokrasi. Pilihan tersebut dikarenakan masa transisi demokrasi paling krusial di pembabakan sejarah politik Chile, tidak terkecuali pembentukan awal bantuan luar negeri.

\section{METODE PENELITIAN}

Penelitian ini merupakan penelitian deskriptif dengan pendekatan kualitatif. Penelitian deskriptif merupakan penelitian tentang permasalahan yang dapat dibuktikan dengan fakta-fakta yang ada (Suharsimi, 1996). Penelitian deskriptif memiliki tujuan untuk menggambarkan secara tepat sifat suatu individu dan fenomena yang sedang terjadi (Alex, 1996).

Menurut Neuman (2014, pp. 3839) tipe penelitian deskriptif adalah tipe penelitian yang mencoba menggambarkan detail yang spesifik atas suatu situasi, keadaan, atau relasi sosial. Tujuan penelitian deksriptif 
yaitu: membuat seperangkat kategori atau tipe pengklasifikasian, mengklarifikasi tata urutan atau rangkaian tahapan, mendokumentasikan proses atau mekanisme, dan melaporkan konteks situasi tertentu. Penelitian deksriptif pada umumnya menggunakan kata tanya "bagaimana (bow)".

Data yang digunakan dalam penelitian ini berjenis data sekunder. Analisis data mengikuti tahapan pengumpulan data dari sumber terpercaya, kategorisasi, reduksi, pemadatan, dan interpretasi data mengikuti alur yang ditawarkan Flick (2013). Walaupun data sekunder mengakibatkan pembacaan berjarak, namun tidak berarti menghalangi munculnya interpretasi yang sesuai atas fenomena sosial yang diteliti.

\section{KERANGKA TEORI}

Penelitian ini memakai teori milik Carol Lancaster. Lancester mencoba untuk menganalisis pengaruh politik domestik dan bantuan luar negeri. Lancaster mencontohkan operasional variabel-variabel pada bab-bab pembahasan tentang negara (lihat Lancaster, 2007, chapter 3-7). Lancester menuliskan bahwa "I have identified four categories of domestic political forces shaping foreign aid: ideas, political institutions, interest, and aid organization" (Lancaster, 2007, 18).

Variabel pertama adalah ide. Ide merupakan gagasan/pandangan atas dunia, nilai bersama (berbasis budaya, agama, ideologi) tentang baik buruk, serta layak - tidak layak di ranah publik dan privat yang berada di elit politik pemerintahan negara (Lancaster, 2007, 18). Pandangan dan nilai merupakan kata kunci dalam kategorisasi ini.

Variabel kedua adalah institusi khususnya institusi politik. Terdapat tiga hal yang membantu melihat bagaimana institusi politik berpengaruh pada foreign aid yakni: electoral rules; hubungan antara badan eksekutif (parlementer/presidensial) dan legislatif negara; dan peran pemerintah lokal serta entitas semi-publik seperti advisory committees dan NGO (NonGovernmental Organization) yang didukung oleh negara. Partai politik dapat memainkan peran dalam hal menentukan jumlah dan tujuan bantuan luar negeri (Lancaster, 2007, 18).

Variabel ketiga yakni interests dilihat melalui kelompok kepentingan yang ada di dalam suatu negara. Terdapat tiga jenis kelompok kepentingan berdasarkan pengaruhnya terhadap foreign aid yaitu: kelompok yang mendukung tujuan komersial dari bantuan yang diberikan; kelompok yang mendukung tujuan pembangunan, kemanusian, dan sebagainya; dan kelompok yang memiliki pertalian etnis atau agama/kepercayaan dengan kelompok di luar negeri yang menjadi tujuan bantuan luar negeri (Lancaster, 2007, 18). 
Variabel keempat, organisasi merupakan agensi atau badan pemerintah yang menaungi program pemberian foreign aid. Semakin banyak tanggung jawab yang dipegang dan disatukan di bawah agensi, semakin besar pula pengaruh agensi atas kebijakan dan program yang dijalankan terkait bantuan luar negeri (Lancaster, 2007, 22).

Bantuan luar negeri didefinisikan sebagai transfer sukarela yang berasal dari publik suatu negara dari suatu negara ke negara berdaulat lainnya, ke $\mathrm{NGO}$, atau ke organisasi internasional dengan komposisi sekurang-kurangnya $25 \%$ dari bentuk transfer tersebut adalah hibah/grant dengan tujuan utama memperbaiki kondisi manusia. Bantuan luar negeri merujuk pada transfer antara negara dan pemerintah berdaulat yang di dalamnya tidak termasuk bantuan militer, kredit ekspor, pembiayaan perdagangan, subsidi untuk investasi swasta, intelejen, pendanaan melawan teroris/pelaku kejahatan internasional, biaya representasi diplomat, atau sumbangan dermawan dari lembaga filantropis. Bantuan dapat berupa uang tunai (hibah atau pinjaman yang longgar-kerelaan/concencional loan) (Lancaster, 2007, pp. 9-11), selain itu dapat berupa asistensi teknis.

\section{ANALISIS DAN PEMBAHASAN}

Bantuan luar negeri merupakan topik penulisan yang banyak diperbincangkan dalam kajian politik internasional, baik dalam sudut teori dan konsep, ekonomi politik, tata kelola, maupun sosial budaya. Morgenthau menulis teori berjudul $A$ Political Theory of Foreign Aid pada tahun 1962 (Morgenthau, 1962).

Beberapa peneliti mempertanyakan efektivitas dan manfaat riil bantuan luar negeri serta apakah bantuan luar negeri betul-betul bekerja sebagaimana mestinya. Beberapa tulisan berakhir dengan nada negatif (Acemoglu and Robinson 2014; Boone 1996; F. Niyonkuru 2016; Moyo 2009; Riddell, 2008).

Bantuan luar negeri dilihat justru melahirkan dan memperumit masalah di negara penerima seperti korupsi, pencarian rente dan sebagainya (Bräutigam \& Knack, 2004; Prokopijevic, 2007; Svensson, 2000). Beberapa karya membahas bantuan luar negeri dilihat dari sudut emerging donors (Emma Mawdsley, 2012; Manning, 2006; Quadir, 2013; Robledo, 2015; Sato et al. 2011). Beberapa karya membahas mengenai bantuan luar negeri yang disediakan oleh negaranegara di kawasan Amerika Latin (Asmus, Fuchs, and Miller, 2017; Vaz and Inoue, 2007).

Salah satu karya yang membahas spesifik Chile dan hubungannya dengan bantuan luar negeri adalah karya milik Alexis Gutiérrez dan Dany Jaimovich. Gutiérrez \& Jaimovich meneliti dari sudut persentase ODA (Official 
Development Assistance) Chile dari rentang tahun 2006-2012 yang menunjukkan persentase ODA $0.01 \%$ dari total GDP (Gross Domestic Product). Gutiérrez \& Jaimovich juga menyatakan ODA berfungsi sebagai instrument soft power bagi Chile (Gutiérrez and Jaimovich, 2017). Namun demikian, belum ada karya yang membahas faktor domestik dan hubungannya dengan bantuan luar negeri Chile. Oleh karenanya, penelitian ini hadir untuk mengisi kekosongan tersebut.

Dalam penelitian ini, menganalisa pengaruh politik domestik terhadap dinamika bantuan luar negeri Chile dilakukan dengan menggunakan teori Lancester yang mempunyai variabel ide, institusi, interest, dan organisasi. Analisa pengaruh akan berada di setiap variabel yang digunakan.

\section{Ide}

Tahun 1990 menandai perubahan struktur politik baik secara substansial maupun simbolik kembalinya tatanan demokrasi Chile setelah 17 tahun sebelumnya hidup dalam tatanan otoriter. Pada konteks ini, AGCI dibentuk awalnya sebagai penyalur bantuan yang didapat dari luar negeri. AGCI pada waktu itu lebih menekankan posisi sebagai penerima bantuan daripada pemberi bantuan (Lahera, 2000, 135).

Koalisi kiri tengah (contertacion) dan Presiden Aylwin mempercayai gagasan kembali ke demokrasi multi-partai adalah jalan terbaik bagi negara mereka. Ideologi kiri tengah menitik beratkan pada perhatian sosial, ketimpangan, pendidikan, belanja sektor sosial, kebutuhan dasar dan sebagainya.

Pembentukan AGCI, yang merupakan cikal bakal agensi yang mengurusi bantuan luar negeri Chile hadir sebagai manifestasi berjalannya kebijakan di rel transisi demokrasi. Gagasan demokrasi tersebut tidak hanya diperkuat oleh kondisi material dalam negeri, tetapi nantinya juga diperkuat oleh faktor luar negeri seperti runtuhnya Uni Soviet atau berakhirnya perang dingin.

Namun seperti setiap negara yang baru saja lepas dari kepemimpinan diktator, kekuatan militer dan dukungan sebagian masyarakat terhadap ide otoriter akibat dari polarisasi politik masih bertahan cukup kuat. Nostalgia kehidupan otoriter yang serba disiplin berbasis terror masih hidup di sebagian masyarkat. Sebagian masyarakat mendelegitimasi gagasan demokrasi sekadar tidak lebih dari medium baru penyedia intrik penipuan ekonomi (korupsi, dan sebagainya). Seperti yang dikatakan Presiden Frei Ruiz bahwa, "Challenge generated by change in our country is the increasing distance and skepticism felt by many of our citizen toward political activity" (Frei dalam Lahera, 2000, 24).

Penguatan demokrasi sebagai sistem gagasan dan politik 
membutuhkan pendanaan, sementara kondisi perekonomian pos-otoritarian awal tidak memadai. Beberapa negara pendonor Eropa Barat menarik keluar bantuan mereka dari Chile semenjak Pinochet menjabat dan mengangkangi Hak Asasi Manusia, serta lebih banyak menerima masukan pengaturan ekonomi dari ekonom chichago boys. Chile terisolasi secara internasional, kecuali dari aliansi tradisional Pinochet yaitu pemerintah Amerika Serikat.

Calleja dan Prizzon (2019, p. 19) menunjukkan data pada tahun 1990, rentang awal transisi demokrasi, ODA yang diterima Chile meningkat menjadi USD 196 juta. Pada tahun 1993 ODA yang diterima Chile meningkat lagi menjadi USD 489 juta. Hampir 50\% ODA yang diterima Chile pada tahun 1993 tersebut berasal dari Amerika Serikat (USD 233 juta), sebagian lainnya dari Perancis (USD 81 juta), dan Jerman (USD 75 juta). Nilai pada tahun 1993 tersebut menjadi nilai tertinggi dalam sejarah ODA yang diterima Chile paska Pinochet sampai saat ini.

Negara donor menujukan bantuannya untuk memperkuat praktik dan nilai demokrasi seperti transparansi, desentralisasi, penegakan HAM dan refromasi lainnya. Gagasan demokrasi dengan partisipasi masyarakat dan pembiayaan sosial berjalan setidaknya menggunakan bantuan donor tersebut.

Ide dan nilai penting yang lain dalam masa awal konsolidasi demokrasi di Chile adalah nilai tradisional Katolik. Nilai ini dianut oleh mayoritas penduduk Chile. Kaum pempimpin gereja Katolik ketika awal konsolidasi menyerukan penegakan HAM dan supremasi sipil sebagai bagian dari penegakan ajaran agama terkait kemanusiaan.

Fleet \& Smith (1997) menuliskan pemerintahan Aylwin membuat Special Commission on Truth and Reconciliation yang melakukan investigasi pelanggaran HAM yang terjadi era Pinochet. Pastor Carlos Gonzales yang ikut dalam komisi khusus tersebut mengatakan rekonsiliasi bisa terjadi ketika masyarakat mengakui kesalahannya dan meminta maaf kepada korban/keluarga korban/masyarakat lainnya. Usaha komisi itu dalam mengungkap kebenaran tidak semudah perkiraan karena pihak militer beberapa kali menyerang balik komisi tersebut. Aylwin dan Pinochet sampai bertemu empat kali untuk bersepakat 1.167 kasus akan diadili, 800 oleh pengadilan sipil, dan sisanya oleh militer. Pada bulan Mei 1992, pemerintahan Aylwin mengajukan proposal untuk membentuk ulang kontrol sipil atas militer, tetapi 23 jenderal militer menandatangani penolakan atas keputusan tersebut dan ingin membuat faksi militer sebagai bagian dari badan pemerintahan/eksekutif.

Dari gambaran tersebut, sekilas dapat dilihat bahwa pemerintahan Aylwin masih sangat susah untuk 
mengontrol militer kembali ke barak. Relasi sipil-militer dalam tensi tinggi karena Pinochet meskipun tidak menjadi presiden lagi, tetap menjadi panglima militer dan anggota senat sampai tahun 1998.

Pandangan Presiden Aylwin, koalisi kiri tengah (concertacion), pemuka agama Katolik, elit NGO dan pemuka masyarakat lainnya berada dalam horizon yang sama yaitu ingin meneggakkan supremasi sipil, membangun nilai dan praktik demokrasi. Permasalahan kekuatan de facto kubu militer masih menjadi batu sandungan terbesar di tengah kondisi ekonomi yang tidak begitu baik (pendapatan negara, kesenjangan, dan sebagainya). Dalam rentang waktu itu, Pinochet berstrategi menunggu pemimpin sipil salah langkah, kemudian mengambil alih kembali.

Pilihan paling rasional dari situasi ini bagi pemerintah Chile adalah mengupayakan kepentingan domestik dengan cara menarik bantuan luar negeri. Cara yang digunakan yaitu dengan memperlihatkan kesungguhan ke dunia internasional terkait upaya konsolidasi demokrasi di Chile.

Memulihkan kepercayaan negaranegara dan menarik simpati agar memberikan bantuan merupakan jalan rasional untuk membantu perekonomian di masa sulit tersebut. Akumulasi kekayaan pebisnis besar berada di kubu konservatif. Lawatan presiden Aylwin ke beberapa negara di Eropa dan Asia juga dalam tujuan yang sama, selain berusaha meyakinkan investasi dan membuka peluang eksporimpor. AGCI hadir dalam konteks ini, menjaga kepercayaan donor bahwa bantuan yang masuk berjalan di rel suatu ide besar yaitu membantu dan mengawal konsolidasi demokrasi yang dijalankan oleh lapisan sipil baik elit, maupun akar rumput.

Klaveren (dalam Lahera, 2000, 142) memaparkan bahwa pada bulan Mei 1990, pemerintahan Aylwin menandatangani Coooperation Framework Agreement dengan EC (European Community). Pada tahun 1996, di masa pemerintahan presiden Frei, perjanjian dengan instrumen yang baru ditandatangani oleh pihak Chile dan EC.

Calleja dan Prizzon (2019, p. 20) menuliskan bahwa bantuan yang didapat dari donor ke pemerintahan Aylwin didistribusikan ke penguatan belanja sosial ke masyarakat kelas bawah. Fokus bantuan berada di sektor pendidikan, kesehatan dan perumahan. Selain itu bantuan transfer pengetahuan ke sumber daya manusia dialokasikan untuk mempersiapkan daya saing sumber daya manusia di Chile.

Pada akhir tahun 1990-an dan awal 2000-an, Chile bertransformasi dari penerima ODA ke mitra kerja sama yang lebih aktif. Nilai ODA yang masuk ke Chile menurun dari $0.38 \%$ pada 
tahun 1993 menjadi $0.01 \%$ pada tahun 1999 berparael dengan naiknya GNI. Beberapa negara donor dari Eropa Barat seperti Belanda, Norwegia, Swedia dan Inggris menarik diri seiring membaiknya kondisi perekonomian di Chile.

Pemerintah Chile bermanuver ke ide outward-looking dengan mulai memberikan bantuan horizontal ke beberapa negara di kawasan Amerika Latin. Bantuan tersebut berupa bantuan teknis dan beasiswa. Pada tahun 1998, Chile mengalokasikan USD 4.2 juta untuk kerjasama Selatan-Selatan melalui program bernama TCDC (Technical Cooperation Among Developing Countries) yang melingkupi beasiswa, bantuan teknis dan kerja sama tiga pihak (triangular cooperation) (Calleja and Prizzon, 2019).

Pemilihan peningkatan sumber daya manusia melalui pendidikan sebagai pilihan program bantuan luar negeri Chile ke negara lain diilhami oleh pengalaman sejarah mereka. Kepercayaan mereka bahwa pendidikan merupakan faktor sangat penting bagi masa depan suatu negara. Sejarah menunjukkan semangat pendidikan era Pinochet sangat menurun. Semangat pendidikan yang turun drastis menurut Richmond (1996) dikarenakan di era Pinochet menerapkan estado docente yaitu kontrol kuat negara pada pendidikan dan mengisolasi pendidikan hanya sekadar mengkaji pembangunan. Intimidasi dan pembungkaman menghilangkan semangat pendidikan sebagai kontrol sosial

Collier dan Sater menyatakan bahwa salah satu kepercayaan pemerintahan concertacion adalah pendidikan merupakan aspek utama untuk memutus rantai kemiskinan. Pemerintah memperhatikan ketimpangan kota besar dan daerah lainnya dalam membuat infrastruktur pendidikan. Bagi pelajar yang miskin disediakan layanan kesehatan, buku gratis, dan suplai lainnya yang dibutuhkan sekolah. Di tahun 2000 sebanyak lebih dari satu juta pelajar sekolah dasar yang mendapat layanan makan siang gratis, angka tersebut meningkat dibandingkan tahun 1990 yaitu sebanyak 680.000 pelajar (Collier and Sater, 2004, 397).

Ide dan gagasan untuk menciptakan demokrasi yang lebih baik daripada era sebelumnya membuat kebijakan publik berjalan di rel yang sama. Keberhasilan transisi demokrasi pada tahun 1990an tidak mungkin terjadi tanpa komitmen yang kuat, meskipun tidak semua pihak dapat terpuaskan.

Jorge Daccarett (2013, p. 163) mengatakan munculnya Chile sebagai pemberi bantuan ke negara SelatanSelatan karena sejak awal tahun 1990 Chile tidak menempatkan diri dan berpikir sebagai negara yang akan terusmenerus menerima bantuan atau traditional recipient. Chile lebih 
menempatkan bantuan dari luar negeri tersebut dalam ide pembelajaran. Ketika ekonomi menguat, Chile lepas landas menjadi negara pemberi bantuan untuk mengatasi masalah-masalah serupa di negara lain yang pernah dihadapi Chile beberapa dekade yang lalu.

\section{Institusi}

Sistem bernegara di Chile menggunakan konstitusi tahun 1980 dengan beberapa kali amandemen. Konstitusi tahun 1980 mencegah junta militer Pinochet berkuasa lama karena seperti yang telah dituliskan sebelumnya Pinochet nantinya kalah dalam plebisit bulan Oktober tahun 1988 (54\% No, 43\% Yes). Konstitusi tahun 1980 menekankan pembagian kekuasaan.

Chile berbentuk negara republik demokrasi yang dipimpin oleh seorang Presiden. Presiden bertindak sebagai kepala negara dan pemerintahan (presidensial). Kongres (dewan legislatif) nasional memakai sistem bikameral (Chamber of Deputies/camara de diputados/dewan perwakilan dan Senat). Dewan perwakilan terdiri dari 120 anggota yang dipiih secara langsung melalui pemilihan elektoral tingkat distrik. Anggota senat dipilih langsung dari 13 daerah, setiap daerah memilih 2 senator. Anggota senat juga terdiri dari presiden sebelumnya, mantan pimpinan mahkamah agung, mantan rektor universitas negeri, mantan jenderal tantara dan polisi dan sebagainya. Kekuasaan ekslusif dewan perwakilan yaitu: mengontrol eksekutif dan militer (constitution, 1980). Kepartaian menganut sistem multi-partai.

Dapat dilihat pada informasi konstitutsi 1980 tersebut bahwa presiden menjadi aktor utama karena menganut sistem Presidensial. Presiden membutuhkan dukungan dari legislatif untuk mengawal kebijakan yang telah dicanangkan. Pada dasar hukum mengenai anggota senat tersebut dapat menjelaskan mengapa Pinochet masih ada dalam senat sampai tahun 1998.

Dalam hal ini, pemerintahan awal transisi demokrasi Presiden Aylwin tidak begitu mendapat oposisi besar dari legislatif. Presiden Aylwin juga merupakan pimpinan partai Christian Democratic yang memimpin koalisi (concertacion) 14 partai oposan kekuasaan Pinochet dan partai konservatif.

Rector (2005, p. 210) menuliskan bahwa partai koalisi kiri tengah tidak hanya memenangkan pemilihan eksekutif Presiden Aylwin melawan calon konservatif yaitu Buchi, tapi juga memenangkan 72 kursi dewan perwakilan (dari 120 kursi) dan 22 senat (dari 38 kursi). Kemenangan tersebut membuat kebijakan transisi demokrasi presiden Aylwin tidak mendapat hambatan berarti dari legislatif.

Pada umumnya di negara dengan sistem multipartai, partai berkuasa akan mengambil sedikit jarak dengan presiden untuk menghindari efek buruk ketika presiden mengambil kebijakan 
salah langkah yang menggoyahkan loyalitas konstituen. Namun pemandangan berbeda di Chile pada masa awal pemerintahan transisi demokrasi, justru partai koalisi tidak berjarak dan cenderung menampilkan identitas dengan terbuka sebagai pengawal demokrasi dan mitra penting eksekutif. Relasi inilah yang memungkinkan kebijakan berjalan (tidak banyak kebuntuan), tidak terkecuali kebijakan tentang bantuan luar negeri.

Polarisasi di legislatif berjalan dengan penegasan polarisai ideologis kiri - kanan, liberal - konservatif. Polarisasi dengan posisi ideologis yang spesifik menjadi penting karena memberikan tanda yang jelas bagi konstituen untuk membaca arah kebijakan. Tidak membingungkan konstituen melihat elit politik di posisi yang kabur dan cari aman.

Hambatan paling berat di awal adalah relasinya dengan militer. Sejalan dengan pernyataan Collier \& Sater (2004, p. 382) bahwa pemerintaha Aylwin pada tahun 1990 mempunyai tiga lapis tugas berat yaitu: relasi sipil militer, menegakkan keadilan HAM, dan menaikkan pertumbuhan ekonomi.

Dalam perjalanan, spektrum kebijakan Presiden Aylwin dengan bantuan sisi legislatif berlanjut di pemerintahan selanjutnya. Kemenangan koalisi kiri tengah membuktikan publik menaruh rasa percaya pada kekuasaan yang berjalan. Koalisi kiri tengah memenagi beberapa kali pemilihan eksekutif.

Berikut merupakan daftar pemenang pemilihan umum di Chile:

Tabel 1. Pemenang Pemilu di Chile

\begin{tabular}{|c|c|c|}
\hline Tahun Pemilu & Presiden Pemenang & Koalisi Partai Pengusung \\
\hline 1993 & Eduardo Frei Ruiz-Tagle & Concertacion (centre-left) \\
\hline 1999 & Ricardo Lagos & Concertacion (centre-left) \\
\hline 2005 & Michelle Bachelet & Concertacion (centre-left) \\
\hline 2009 & Sebastian Pinera & Coalition for Change (centre-right) \\
\hline 2013 & Mihelle Bachelet & New Majority (centre-left) \\
\hline 2017 & Sebastian Pinera & Chile Vamos (centre-right) \\
\hline
\end{tabular}

Sumber: (BBC News 2017; Cussen 2013; Huber and Stephens 2012; Mayer 2014).

Mayoritas dari program bantuan luar negeri bilateral Chile melalui AGCI merupakan respon dari prioritas kebijakan luar negeri administrasi presiden yang menjabat (Jaimovich, 2016). Perubahan dinamika bantuan luar negeri Chile yang pada mulanya didominasi oleh bantuan sosial menjadi bantuan ekonomi disebabkan oleh perubahan partai politik pemenang pemilu Chile dari masa ke masa. Ideologi presiden dan partai berkuasa 
tetap menjadi hal yang penting terhadap dinamika alokasi bantuan luar negeri.

Pada tiga periode pertama, koalisi partai pemenang pemilu merupakan koalisi kiri tengah yang melihat bantuan luar negeri ditujukan untuk pembangunan mereka yang kurang beruntung. Namun seiring meningkatnya kepercayaan masyarakat terhadap pertumbuhan ekonomi, bantuan luar negeri mulai diarahkan pada sektor ekonomi dan yang lebih profesional mengikuti standar OECD DAC.

Kerja sama bilateral juga terus dieratkan dan diperbanyak. Bergeraknya Chile dari negara aid-receiving ke aid-giving mengangkat kemampuan pergaulan internasional terutama dengan negaranegara maju. Menurut Emma (2012) peran ganda (recipient \& provider) mencari ciri khas awal negara emerging donors.

Kecenderungan koalisi partai pemenang sangat memengaruhi bagaimana mereka mengeluarkan kebijakan terkait bantuan luar negeri. Pada pemilu tahun 2017 contohnya, koalisi partai pemenang pemilu adalah Chile Vamos yang terdiri dari empat partai center-right dan right-wing yaitu National Renewal, Independent Democratic Union, dan Political Evolution. Keinginan Vamos untuk mendukung pasar bebas, mencapai pertumbuhan ekonomi, serta mengembalikan peringkat Chile sebagai salah satu negara dengan perekonomian paling bebas tercermin dalam bantuan luar negeri yang lebih diarahkan untuk tujuan diplomatik seperti mendorong pasar bebas dan membangun infrastruktur ekonomi (Roberts, 2018).

Aktor publik yang juga turut memengaruhi politik dalam negeri yang nantinya berefek pada bantuan luar negeri ialah pemuka agama Katolik. Jejaring pemuka agama politik juga berperan dalam transfer kekuasaan yang relatif mulus di Chile dari Pinochet ke Aylwin. Kondisi para pemuka agama dalam rezim Pinochet juga mengalami kegetiran.

Sebelum plebisit, pada Januari 1987 Paus John Paul II bertemu Pinochet. Kedatangan tersebut menurut Fleet \& Smith (1997) sangat berarti dan strategis karena membantu mengurangi polarisasi yang ada, mengingatkan kubu komunis untuk tidak menggunakan kekerasan untuk menurunkan Pinochet (kontraproduktif), membuat kubu oposisi semakin percaya diri, dan pertama kalinya lagi masyarakat turun memadati jalan (memberikan semangat). Aktor pemuka agama memainkan peran signifikan dalam pemenangan opsi “tidak” pada plebisit 1988.

Seperti yang telah dijelaskan sebelumnya, setelah Aylwin naik pihak gerejawan banyak membantu pemerintah di isu HAM. Pihak gerejawan kemudian lebih banyak masuk pada isu sosial dan moral seperti perceraian dan sebagainya. Intelektual dan ilmuwan Katolik berkiprah pada pendidikan dengan penguatan 
universitas Katolik seperti Pontificia Universidad Católica de Chile. Kampus ini yang menyokong bantuan luar negeri untuk pelajar yang mencari beasiswa ke Chile, maupun proyek di luar negeri seperti pembangunan sekolah di Haiti pasca gempa bumi tahun 2010.

\section{Interests}

Kelompok kepentingan yang utama pada awal terbentuknya AGCI adalah pemerintah itu sendiri melalui MIDEPLAN (Ministry of Planning and Social Development Cooperation). Kepentingannya adalah memosisikan AGCI sebagai badan resmi yang mengurusi bantuan luar negeri yang masuk ke Chile.

MIDEPLAN tergolong sebagi aktor pendukung bantuan non komersil atau tujuan yang lebih menitikberatkan pada isu sosial dan pembangunan. Kemudian ada kelompok bernama FOSIS (Fund of Social Solidarity and Investment). FOSIS banyak melatih pengembangan wiraswasta kecil menengah. Javier \& Fuentes 245 (dalam Lahera 2000, 245) menuliskan bahwa dari tahun 1991 sampai 1995 FOSIS mendampingi 60.000 pengusaha skala kecil menengah dan memberi fasilitas kredit, konsultasi, dan pelatihan. Sampai pada tahun 1997, USD 14 juta anggaran dialokasikan untuk program FOSIS.

Lambrou (1997) menyatakan bahwa setelah restorasi demokrasi, relasi negara dan NGO didefinisikan dan ditata kembali. Sinkronisasi tidak hanya berjalan pada tataran ide, melainkan struktur dan teknis. Penataan ulang ini dimungkinkan karena semangat menghidupkan demokrasi yang sama. FOSIS menyalurkan programnya kepada kelompok masyarakat dan NGO. NGO OPDECH (Officiana Promotora del Desarrollo Chilote), misalnya, sebagai NGO di akar rumput sektor agrikultur tetap bergerak memajukan pertanian, bermitra dengan pemerintah sambil menyeimbangkan diri agar tidak tergerus perekonomian neo-liberal.

NGO memberikan warna tersendiri bagi pemerintahan transisi demokrasi di Chile menyangkut pengelolaan bantuan, teknis di lapangan, dan sebagainya. Ketika Chile lepas landas memberikan bantuan ke negara lain, para eksper NGO membantu desain dan pelaksanaan program di luar negeri. Dukungan tersebut membuat dinamika tersendiri terhadap bantuan luar negeri. Sektor agrikultur nantinya menjadi sektor andalan bantuan luar negeri Chile baik kerja sama bilateral, triangular, maupun multilateral dengan semangat horizontal dan kerja sama Selatan-Selatan.

Di luar pemerintahan, terdapat kepentingan dari kelompok penekan domestik yakni serikat buruh Chile yang memiliki tujuan untuk mendapatkan kesejahteraan bagi kaum buruh dan berafiliasi dengan International Trade Union Confederation. Keduanya memiliki 
tujuan utama yang sama yaitu membawa isu kesejahteraan kaum buruh ke dalam pertimbangan kebijakan pembangunan internasional (ITUC, 2020).

Untuk kelompok penekan dari sisi pebisnis, Silva (1996) menuliskan bahwa hubungan awal Aylwin dengan pebisnis besar tidaklah harmonis. Aylwin dan koalisi concertacion menekankan bisnis berjalan sesuai dengan konsensus demokrasi yang dicanangkan yaitu berpihak pada keadilan sosial. Bagi pebisnis hal tersebut kurang menguntungkan dan aman. Tidak bertemunya dua titik ini membuat beberapa kali pembicaraan tidak menemui hasil yang memuaskan. Para pebisnis besar mayoritas berada di kubu konservatif.

CPC (Confederation for Production and Commerce) merupakan kelompok pebisnis besar di Chile yang terbentuk sejak 1943. CPC menjadi kelompok pebisnis dan pelobi yang paling berpengaruh sampai saat ini. CPC menjadi aktor utama pebisnis yang menyangga beberapa presiden Chile sampai saat ini (Hernán Rodríguez Fisse; Clive S. Thomas, 2014).

\section{Organisasi}

Secara visual dinamika pengelolaan bantuan luar negeri Chile melalui AGCI dapat dilihat pada gambar di bawah ini:
Gambar 1. Bantuan Luar Negeri Chile

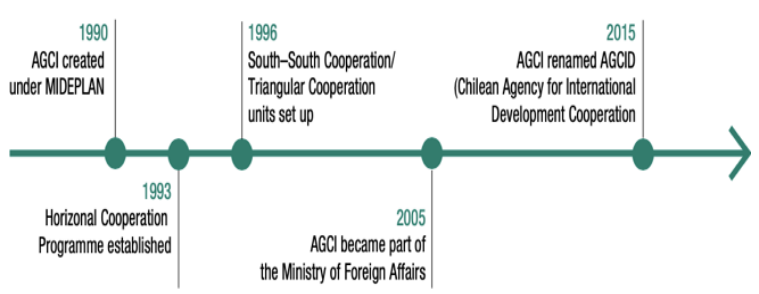

Sumber Calleja and Prizzon, 2019.

Seperti yang telah dijelaskan sebelumnya, awal AGCI berdiri tahun 1990 dibawah koordinasi MIDEPLAN. Orientasi awal AGCI adalah mengelola bantuan asing yang masuk ke Chile lalu menyalurkannya lagi ke beberapa lembaga domestik. Titik beratnya pada pembangunan sosial, wirausaha skala kecil menengah, pendidikan, kesehatan dan beberapa sektor lainnya. AGCI pada mulanya lebih inward-looking.

Seiring dengan menurunnya ODA yang masuk ke Chili akhir 1990-an dan awal 2000-an ditambah lagi dengan perbaikan performa ekonomi Chile, perlahan AGCI menjadi aktor internasional melalui pemberian bantuan bilateral, triangular, maupun multilateral.

Pada tahun 2005, AGCI berada dalam garis koordinasi Kementerian Luar Negeri Chile. Secara simbolis, birokrasi dan riil, hal ini menegaskan bahwa AGCI menjadi instrumen politik dan kebijakan luar negeri karena mengusung visi dan misi kementerian yang menaunginya.

Dinamika bantuan luar negeri Chile yang lebih ourward-looking memosisikan Chile sebagai emerging 
donors. Tujuan posisi ini beragam, misalnya membentuk identitas pendonor dan sebagai negara yang berhasil melalui proses politik, menyebarluaskan pengalaman, sejajar dengan negara pendapatan menengah atas, menjadi jembatan negara menengah bawah dan atas, kepentingan dukungan suara di fora internasional, menguatkan kelompok bisnis domestik, menjadi aktor penting integrasi di kawasan dan sebagainya.

Perubahan pengelolaan ke dalam struktur kementerian luar negeri juga resiprokal dengan kementerian itu sendiri. Untuk berbagai negosiasi, lobi, dan sebagainya, kementerian mempunyai aktor yang berpengalaman dalam melakukan lobi, perundingan dan sebagainya demi mencapai kepentingan nasional Chile. Upaya sinkronisasi coba diterapkan pemerintah Chile dengan merubah posisi AGCI secara tatanan kelembagaan, walaupun tentu saja terdapat dinamika internalnya sendiri.

Karakteristik bantuan luar negeri yang terlihat mirip dengan negara emerging donors di Amerika Latin lainnya, misalnya Brazil. Karakteristik southern turn yaitu semangat kerja sama SelatanSelatan dan horizontal. Peran ganda sebagai penerima dan pemberi bantuan khas negara emerging donors. Sektor bantuan luar negri pun semakin luas tidak hanya di sektor sosial, pendidikan, budaya, agrikultur, namun merambah pada tata kelola, energi, lingkungan, dan keamanan.
Semakin memenuhi standar arus utama, pada tahun 2010 Chile bergabung dengan OECD sekaligus observer dalam DAC. Concessional finance untuk pembangunan digelontorkan pemerintah Chile senilai USD 49 juta pada tahun 2014 dan USD 33 juta pada tahun 2015. Melalui kanal organisasi multilateral, Chile menyalurkan bantuan senilai USD 22.8 juta pada tahun 2015 (OECD, 2020).

Dibalik semua kisah sukses melewati masa transisi demokrasi serta pertumbuhan ekonomi itu, Chile masih menyimpan pekerjaan besar di dalam negeri menyangkut ketimpangan ekonomi. Pada tahun 2015, 10\% penduduk mengakumulasi $57.7 \%$ dari total pendapatan di Chile (Rodríguez, 2020, p. 115). Koefisien GINI Chile berada pada angka 0.56 pada tahun 1987, 0.52 pada tahun 2000, dan 0.44 pada tahun 2017 (World Bank, 2020).

Koefisien GINI tersebut menceritakan bahwa ada penurunan ketimpangan, namun masih berada di angka yang belum baik. Ketimpangan yang lebar telah ada bahkan sebelum transisi demokrasi terjadi. Oleh karena itu, transisi demokrasi tidak terlalu banyak merubah struktur ekonomi neoliberal. Pemain lama, seperti yang telah dijelaskan sebelumnya yaitu CPC, masih menjadi pemain utama di sektor ekonomi Chile. Karena bukan revolusi, pergantian pucuk kepemimpinan hanya memodifikasi struktur ekonomi, namun tidak merubahnya. 
CPC berperan signifikan dalam kebijakan luar negeri dengan memberi masukan dan konsep. Beberapa inisiatif, data, dan konsep diajukan oleh CPC yang kemudian dieksekusi oleh AGCI, terutama ketika AGCI aktif sebagai mitra kerja sama di luar negeri (Barros, 2014). CPC menjadi kelompok kepentingan dan penekan utama sektor bisnis dan komersil dalam kebijakan dalam dan luar negeri Chile, tidak terkecuali melalui AGCI baik melalui jalur bilateral, triangular, trilateral, dan multilateral.

\section{KESIMPULAN}

Politik domestik memengaruhi dinamika bantuan luar negeri Chile, meminjam teori Lancaster, dapat dilihat dari gugus ide, institusi, kelompok kepentingan, dan organisasi. Pada kasus Chile ide tentang demokrasi dan kemanusiaan menjadi penting sebagai landasan berpikir. Memperbanyak belanja sosial dan investasi sumber daya manusia khususnya pendidikan untuk masyarakat menjadi gagasan ide kiri tengah di rentang tahun 1990-an.

Pengalaman historis yang sangat material yaitu kemunduran di era Pinochet, membuat elit oposisi dan masyarakat mempunyai suatu pandangan yang sama. Era awal ini ditandai dengan tantangan yang paling berat yaitu relasi sipil - militer. Militer masih memegang sebagian kendali dan mencoba memengaruhi pemerintahan sipil. Posisi AGCI menjadi penting sebagai lembaga yang mengelola bantuan luar negeri Chile yang tepat sasaran. Hal ini meyakinkan pendonor luar negeri terhadap belanja bantuan berjalan pada rel demokrasi penguatan masyarakat sipil dan terhindar dari kooptasi militer.

Ketika pertumbuhan ekonomi membaik, ide internasionalisasi AGCI dicanangkan dengan mensinkronkan kelembagaan dalam koordinasi kementerian luar negeri. Secara institusi, koalisi partai dan pemerintahan awal berjalan selaras. Dinamika perubahan bantuan luar negeri bergantung pada haluan ideologis pemimpin dan partai berkuasa.

Kelompok kepentingan, yang menjadi kelompok penekan, memegang peranan kunci dalam memengaruhi dinamika bantuan luar negeri Chile. CPC merupakan aktor di luar pemerintah yang sangat sentral memengaruhi fenomena ini. Secara pengelolaan organisasi, perubahan birokrasi menandai dinamika orientasi bantuan luar negeri.

Teori Lancaster kurang pada penekanan agensi/aktor khususnya elit. Teori ini banyak mengulas struktur, namun masih ada kekurangan dalam melihat struktur ekonomi politik yang berjalan atau perubahan yang terjadi di dalamnya. Terkait konteks politik di kawasan Amerika Latin, posisi ideologis pemimpin, elit, atau partai berkuasa menjadi hal yang penting untuk diamati. 


\section{REFERENSI}

Acemoglu, D. (2014) Why foreign aid fails and how to really help Africa. Retrieved June 3, 2020, from The Spectator website: https://www.spectator.co.uk/article/wh y-foreign-aid-fails---and-how-to-reallyhelp-africa

Aedo-Richmond, R., \& Richmond, M. (1996). Recent Curriculum Change in PostPinochet Chile. Compare: A Journal of Comparative and International Education, 26(2), 197-215. https://doi.org/10.1080/030579296026 0205

Alex, M. (1996). Metode Penelitian Kualitatif. Bandung: Remaja Rosdakarya.

Asmus, G., Fuchs, A., \& MMller, A. (2017). BRICS and Foreign Aid. SSRN Electronic Journal. https://doi.org/10.2139/ssrn.3027620

Barros, M. G. (2014). AGCI: Análisis de la cooperación para el comercio en el marco de la colaboración sur-sur como instrumento de politica exterior otorgada en América Latina durante el periodo 2006-2013. https://doi.org/10.16526/j.cnki.114762/tp.2014.11.051

BBC News. (2017). Chile election: Conservative Piñera to face Socialist Guillier in run-off. Retrieved June 4, 2020, from https://www.bbc.com/news/worldlatin-america-42047530

Boone, P. (1996). Politics and the effectiveness of foreign aid. European Economic Review, 40(2), 289-329. https://doi.org/10.1016/00142921(95)00127-1

Bräutigam, D. A., \& Knack, S. (2004). Foreign aid, institutions, and governance in sub-Saharan Africa. Economic Development and Cultural Change, 52(2), 255-285. https://doi.org/10.1086/380592

Calleja, R., \& Prizzon, A. (2019). Moving away from aid The experience of the Republic of Korea. London.
Collier, S., \& Sater, W. F. (2004). A History of Chile, 1808-2002. In A History of Chile, 1808-2002.

https://doi.org/10.1017/cbo978051199 1189

Constitution of the Republic of Chile. , (1980).

Cussen, C. (2013). In Chile's Sunday elections, the real race is for second place. Retrieved June 1, 2020, from The Washington Post website: https://www.washingtonpost.com/blogs /she-the-people/wp/2013/06/28/inchiles-sunday-elections-the-question-iswho-will-finish-second/

Emma Mawdsley. (2012). From recipients to donors: Emerging powers and the changing development landscape. London: Zedbooks.

F. Niyonkuru. (2016). Failure of Foreign Aid in Developing Countries: A Quest for Alternatives. Business and Economics Journal, 7(3), 1-9. https://doi.org/10.4172/21516219.1000231

Fleet, M., \& Smith, B. H. (1997). The Catholic Church and Democracy in Chile and Peru. University of Notre Dame Press.

Flick, U. (2013). The SAGE Handbook of Qualitative Data Analysis. SAGE Publications.

Gutiérrez, A., \& Jaimovich, D. (2017). A new player in the international development community? Chile as an emerging donor. Development Policy Review. https://doi.org/10.1111/dpr.12266

Hernán Rodríguez Fisse; Clive S. Thomas. (2014). The Chilean big business lobby: a long- standing and major influence on public policy. Journal of Public Affairs, 14(3), 310-330. https://doi.org/10.1002/pa.1520

Huber, E., \& Stephens, J. D. (2012). Democracy and the Left: Social Policy and Inequality in Latin America. Chicago University Press.

John L. Rector. (2005). The History of Chile. 
Kirk, J. M. (2015). Healthcare Without Borders. In Healthcare Without Borders. The University press of florida.

Klein, N. (2007). The Shock Dotrine: The Rise of Disaster Capitalism. New York: Henry Holt \& Co.

Lahera, C. T. E. Chile in the nineties., (2000).

Lambrou, Y. (1997). The Changing Role of NGOs in Rural Chile after Democracy. Bulletin of Latin American Research, 16(1), 107-116.

Lancaster, C. (2007). Foreign Aid Diplomacy, Development, Domestic Politics. Chicago: The University of Chicago Press.

Manning, R. (2006). Will "emerging donors" change the face of international cooperation? Development Policy Review. https://doi.org/10.1111/j.14677679.2006.00330.x

Mayer, P. J. (2014). Chile: Political and Economic Conditions and U.S. Relations.

Morgenthau, H. (1962). A Political Theory of Foreign Aid. American Political Science Review. https://doi.org/10.2307/1952366

Moyo, D. (2009). Dead Aid, Why aid is not working. Dead Aid: Why Aid Is Not Working and How There Is a Better Way for Africa.

https://doi.org/10.1016/j.thorsurg.2010. 01.001

Neuman, W. L. (2014). Social Research Methods Qualitative and Quantitative Approaches. Pearson.

OECD. (2013). Development Cooperation Report 2013: Ending Poverty.

OECD. (2020). Chile's Development Cooperation. Retrieved June 2, 2020, from https://www.oecd.org/dac/dacglobal-relations/chiles-development-cooperation.htm

Prokopijevic, M. (2007). Why foreign aid fails. Panoeconomicus, 54(1), 29-51. https://doi.org/10.2298/pan0701029p

Quadir, F. (2013). Rising donors and the new narrative of "South-South" cooperation: What prospects for changing the landscape of development assistance programmes? Third World Quarterly. https://doi.org/10.1080/01436597.2013. 775788

Riddell, R. C. (2008). Does foreign aid really work? Oxford: Oxford University Press.

Roberts, J. (2018). Chile's Economic Freedom Slumped Under SocialismPresident Piñera's Plan Will Revitalize It.

Robledo, C. (2015). New donors, same old practices? South-South Cooperation of Latin American emerging donors. Bandung: Journal of the Global South, 2(3), 1-16. https://doi.org/10.1186/s40728014-0008-0

Rodríguez, J. (2020). Resisting Neoliberal Capitalism in Chile. The possibility of Social Critique.

https://doi.org/https://doi.org/10.1007 /978-3-030-32108-6

Sato, J., Shiga, H., Kobayashi, T., \& Kondoh, H. (2011). "Emerging donors" from a recipient perspective: An institutional analysis of foreign aid in Cambodia. World Development. https://doi.org/10.1016/j.worlddev.201 1.04 .014

Silva, E. (1996). From Dictatorship to Democracy: The Business-State Nexus in Chile's Economic Transformation, 19751994. Comparative Politics, 28(3), 299-320. https://doi.org/10.2307/422209

Suharsimi, A. (1996). Prosedur penelitian: suatu pendekatan praktek. Jakarta: Bima Aksara.

Svensson, J. (2000). Foreign aid and rentseeking. Journal of International Economics, 51(2), 437-461.

https://doi.org/10.1016/S00221996(99)00014-8

Vaz, A. C., \& Inoue, C. Y. A. (2007). Emerging Donors in International Development Assistance: The Brazil case. ... ), International Development Research Centre (Idrc).

World Bank. (2020). GNI per capita - Chile. Retrieved June 2, 2020, from https://data.worldbank.org/indicator/N Y.GNP.PCAP.PP.CD?locations $=\mathrm{CL}$ 